\title{
Neonatal appendicitis: a survival case study
}

\author{
Apendicite neonatal: um estudo de caso de sobrevida \\ Apendicitis neonatal: un estudio de caso de sobrevida
}

\section{Izabela Linha Secco', Taine Costa', Etiene Letícia Leone de Moraes", Márcia Helena de Souza Freire", Mitzy Tannia Reichembach Danski", Regina Paula Guimarães Vieira Cavalcante ${ }^{\text {III }}$}

\author{
' Hospital Infantil Waldemar Monastier, Neonatal Intensive Care Unit. Campo Largo, Paraná, Brazil. \\ "Universidade Federal do Paraná, Postgraduate Program in Nursing. Curitiba, Paraná, Brazil. \\ I' Universidade Federal do Paraná, Health Science Sector, Department of Pediatrics. Curitiba, Paraná, Brazil.
}

\section{How to cite this article:}

Secco IL, Costa T, Moraes ELL, Freire MHS, Danski MTR, Cavalcante RPGV. Neonatal appendicitis: a survival case study. Rev Bras Enferm [Internet]. 2017;70(6):1296-300. DOI: http://dx.doi.org/10.1590/0034-7167-2016-0610

\section{Submission: 12-06-2016 Approval: 02-10-2017}

\begin{abstract}
Objective: To report a case of neonatal appendicitis in a children's hospital in southern Brazil, demonstrating the impact on neonatal survival. Method: Case study with data collection from medical records, approved by the Institution and Ethics Committee for Research with Human Beings. Results: The clinical picture is initially characterized by food intolerance, evolving to hypoactivity, alteration of vital signs and septicemia due to intestinal perforation. Management is exclusively surgical, since no case described in the literature was diagnosed preoperatively and the findings usually point to acute abdomen. Conclusion: A focused clinical surveillance should be established when the infant presents peritoneal irritation. Follow-up of the evolution and the worsening of the symptoms by nurses, as part of the care team in partnership with the medical team, enables an early surgical intervention, thereby avoiding complications such as septicemia and death.
\end{abstract}

Descriptors: Appendicitis; Neonatal Intensive Care Unit; Nursing; Neonate; Survival.

\section{RESUMO}

Objetivo: Divulgar um caso de apendicite neonatal ocorrido em um hospital infantil do Sul do Brasil, evidenciando o impacto na sobrevida do neonato. Método: Estudo de caso com coleta de dados em prontuário, aprovado pela Instituição e pelo Comitê de Ética em Pesquisa com Seres Humanos. Resultados: O quadro clínico é caracterizado inicialmente por intolerância alimentar, evoluindo para hipoatividade, alteração de sinais vitais e septicemia por perfuração intestinal. A conduta é exclusivamente cirúrgica, pois nenhum caso descrito na literatura foi diagnosticado no pré-operatório e os achados normalmente voltam-se para abdome agudo. Conclusão: Deve-se estabelecer uma vigilância clínica enfocada quando o recém-nascido apresenta quadro de irritação peritoneal. O acompanhamento da evolução e a piora dos sintomas pela enfermagem, como parte da equipe de cuidado e parceira da equipe médica, propicia intervenção cirúrgica precoce, evitando complicações como septicemia e óbito. Descritores: Apendicite; Unidade de Terapia Intensiva Neonatal; Enfermagem; Recém-Nascido; Sobrevida.

\section{RESUMEN}

Objetivo: Divulgar un caso de apendicitis neonatal ocurrido en un hospital infantil del Sur de Brasil, evidenciando el impacto en la sobrevida del neonato. Método: Estudio de caso con coleta de datos en prontuario, aprobado por la Institución y por El Comité de Ética en Pesquisa con Seres Humanos. Resultados: El cuadro clínico es caracterizado inicialmente por intolerancia alimentar, evolucionando para hipoactividad, alteración de señales vitales y septicemia por perforación intestinal. La conducta es exclusivamente quirúrgica, pues ningún caso descrito en la literatura fue diagnosticado en el preoperatorio y los allazgos normalmente se vuelven hacia el abdomen agudo. Conclusión: Se debe establecer una vigilancia clínica enfocada cuando el recién nacido presenta cuadro de irritación peritoneal. El acompañamiento de la evolución y la empeora de los síntomas por la enfermería, como parte del equipo de cuidado y asociación del equipo médico, propicia intervención quirúrgica precoz, evitando complicaciones como septicemia y óbito.

Descriptores: Apendicitis; Unidad de Terapia Intensiva Neonatal; Enfermería; Recién Nacido; Sobrevida. 


\section{INTRODUCTION}

In the literature consulted, neonatal appendicitis (NA) is described as an extraordinarily rare entity ${ }^{(1)}$. Although common in the pediatric population, appendicitis in newborns is rarely considered as a differential diagnosis in acute abdomen, and is an infrequent occurrence in children under two years of age, affecting only $2 \%$ of children in this age group ${ }^{(2)}$. It is pointed out that NA corresponds to only $0.04 \%-0.2 \%$ of cases in children under two years with less than 50 cases described in the last 30 years ${ }^{(3)}$.

It is predominant in males in the proportion of $3: 1$ and in preterm newborns compared to those born full term $(52 \%$ and $48 \%$, respectively $)^{(1)}$. However, lethality is high, since the clinical course of the disease can be rapid with death occurring within the first 24 hours after onset of symptoms. Thus, early diagnosis and immediate intervention can reduce mortality secondary to perforation and peritonitis ${ }^{(4)}$ and consequently contribute to the reduction of early neonatal mortality.

The main factor that contributes to diagnostic delay is the low level of suspicion of NA in newborns, even with subtle clinical presentation already installed and which is erroneously treated as necrotizing enterocolitis (NEC) ${ }^{(2)}$. According to studies, the rarity of the inflammatory process in the vermiform appendix during the neonatal period is attributed to its still embryonic morphology, i.e. in a conical form with a broad base and less prone to obstruction. Thus, the investigation turns to $\mathrm{NEC}^{(4)}$. Even when suspected, the diagnosis is still late in all cases and only confirmed during the exploratory laparotomy intraoperative period ${ }^{(5)}$.

Therefore, due to the high lethality rate, the delay in NA management exposes the neonate to a fatal evolution. The presence of abdominal distension, signs of impairment in the general condition, such as hypoactivity, hypothermia and acrocyanosis, in addition to cutaneous signs such as erythema and rapidly evolving abdominal wall edema may be indicative of an immediate surgical procedure ${ }^{(4)}$.

This case report covers a case of NA that occurred in a children's hospital in the southern region of Brazil, which demonstrates how a multi-professional team qualified for a timely intervention has a great impact on neonatal survival. The nurse should be able to recognize changes in the signs and symptoms indicative of this pathology, in order to decrease the time of diagnosis and thereby increase the survival chances of the newborn. For this, the SAE [Nursing Care Systematization] is an indispensable tool, characterized as a method that enables nurses to exercise the art of caring by providing individualized care to the patient, planning their management, analyzing the history with an integral perspective and performing physical examination, in order to diagnose and provide an integral and individualized care for each human being ${ }^{(6)}$.

\section{METHOD}

A case study with a qualitative approach is reported in order to demonstrate the urgency of the multidisciplinary team action given the abdominal clinical signs and symptoms that newborns can present. These are often recognized and treated initially as NEC or acute abdomen, which are more common pathologies in this age group.

The scenario of this case was a children's hospital in the metropolitan region of Curitiba, attending patents up to 18 years of age. Currently, the hospitalization units have 22 surgical pediatrics beds, clinical pediatrics 34, psychiatry four and three units of isolation. It also has two Intensive Care Units - Neonatal with 20 beds and Pediatric with eight beds, a Surgical Center with five active rooms, Emergency Room and Ambulatory of Medical Specialties.

Annotations were retrieved from electronic patient records and the literature was consulted through scientific articles related to the topic. The databases searched were SciELO, Pubmed, International Periodicals and Google Scholar, starting in the year 2000.

This project was approved by the Ethics Committee of Hospital do Trabalhador de Curitiba, and respected the ethical precepts of resolution 466 dated 2012. Consent was granted by the Clinical Board and the Nucleus of Education and Research of the hospital that attended the newborn in this case study.

\section{RESULTS}

Mother of 20 years, second pregnancy and two births, six prenatal consultations, blood typing A+, VDRL, HIV, HbsAg and anti-HCV negative, immune to toxoplasmosis. In this gestation, presented positive uroculture for Enterococcus on 03/05/2013, was treated with cephalexin and presented negative uroculture on 01/13/2013. However, she had a recurrence of urinary tract infection on 08/16/2013, this time being hospitalized and medicated with intravenous ampicillin. However, during the period of hospitalization, she developed preterm labor.

He was born on 03/09/2013 at 3:37 pm, male, initials M.H.O., preterm 30 weeks (Parkim), vaginal delivery with pelvic presentation, weighing 1,510g, Apgar 2/6/8. His birth conditions were worrisome due to hypotonia and bradycardia, requiring positive pressure ventilation and inhaling oxygen to blush. The neonate evolved with motility, underwent non-invasive CPAP ventilation and stabilized. A vacancy was requested through the Central de Cama de Paraná in the children's hospital and the newborn was admitted on 03/09/2013 at 10:00 pm. After clinical evaluation performed by the medical team, the following diagnoses were presented: prematurity, however, appropriate for gestational age (AGA), perinatal asphyxia, potentially infected, jaundice and anemia. After admission, a multi-professional care plan was prepared, with assessments and daily discussions for adjustments as necessary.

Although all interventions pertinent to the care of premature newborn were performed, at day 16 of life he presented unsaturation and abdominal distension, when fasting and basic infusion plan were initiated. Radiography presented distension of mesogastric or hypogastric loops, suggestive of NEC. The patient was also screened with biochemical tests, but all results were normal. On the following day he maintained saturation reductions and also evolved hypoactivity and skin 
mottling, requiring hood oxygen therapy at $40 \%$, but was intolerant, stabilizing only under CPAP at 25\%. However, on 09/22/2013 he was intubated due to apnea. New tests were started to screen for infectious disease: abdominal radiography, demonstrating less air in lower right flank loops; arterial gasometry with metabolic acidosis; positive PCR - $6.4 \mathrm{mg} / \mathrm{dL}$ and still normal blood count.

The evaluation performed by the pediatric surgery team, found presence of mass in the lower right flank and little pain on palpation. Diagnostic imaging examinations were requested and abdominal ultrasound showed increased vascular perfusion in the region, with no mass effect and a small accumulation of fluid in the abdominal cavity. The newborn was sent immediately to the surgical center for exploratory laparotomy, which identified cecum blockage with the anterior abdominal wall, as well as a perforated and gangrenous cecal appendix. Appendectomy was performed together with revision of the peritoneal cavity and cleaning with warm saline solution. The biopsy report confirmed the diagnosis of acute gangrenous appendicitis and acute fibrinosuppurative periappendicitis.

M.H.O. returned to the Neonatal Intensive Care Unit sedated and in invasive mechanical ventilation, with normal vital parameters, except for hypothermia. He evolved with hypotension of $34 \mathrm{~mm} \mathrm{Hg}$ and capillary refill time under 4 seconds, requiring volumetric expansion and continuous infusion of Dopamine. Cefepime and Metronidazole were initiated for seven days, in addition to Amikacin for five days. He remained in absolute fasting with intravenous nutritional support for eight days.

He progressed to ambient air and was discharged to the Internment Unit on postoperative day 45 and received discharge after 69 days of hospitalization. The mother was instructed to return for previously scheduled outpatient appointments for a baby at risk in the neuropediatric and pediatric surgery sectors. According to the institutional protocol, high-risk newborns are followed up to the seventh year of life. However, she last attended a consultation on March 11, 2014, with six months, predominantly breastfeeding plus a complement with Nestogeno $^{\circledR}$, appropriate growth curves and attending day care. Recommendations were made regarding the introduction of fruit into the diet and scheduled to return in two months, however, she was absent on this date.

\section{Care planning and implementation}

Considering that timely diagnosis and prompt surgical intervention are essential for neonatal survival, the importance of knowing the pathophysiology and multi-professional monitoring of the patient is emphasized.

Thus, the nursing diagnoses according to the North American Nursing Diagnosis Association (NANDA) ${ }^{(7)}$, divided into domains, in addition to the prescribed care which was offered to the newborn and family, are presented below.

\section{Domain 2 - Nutrition}

Diagnoses: Ineffective breastfeeding; Risk for unstable blood glucose level; Risk for imbalanced fluid volume; Imbalanced nutrition: less than body requirements.
Nursing prescriptions: administer the diet according to medical prescription; verify activity and reactivity of the newborn; report capillary glycemia less than 45 or greater than $150 \mathrm{mg} / \mathrm{dL}$; record losses and gains in the water balance; weigh the newborn daily; skin turgor monitoring.

\section{Domain 3 - Elimination and exchange}

Diagnoses: Risk for dysfunctional gastrointestinal motility; Impaired gas exchange.

Nursing prescriptions: note frequency and appearance of bowel movements; verify gastric stasis; note episodes of emesis; report abdominal distension; maintain continuous pulse oximetry; report saturation below $85 \%$, cyanosis, tachypnea, respiratory effort, tachycardia, and sudoresis; report hypoactivity or irritability.

\section{Domain 4 - Activity/rest}

Diagnoses: Disturbed sleep pattern; Sleep deprivation; Decreased cardiac output; Ineffective breathing pattern; Risk for decreased cardiac tissue perfusion; Impaired spontaneous ventilation.

Nursing prescriptions: keep the environment quiet throughout the period and penumbra on the incubator; perform restricted and grouped handling; report episodes of bradycardia and tachycardia; report dyspnea, changes in skin color, oliguria, cold and tacky skin, and prolonged peripheral perfusion; position the newborn in a neutral position; attention to nasal flutter, respiratory pause, and apnea; report capillary refill time greater than 3 seconds and cyanosis of extremities.

\section{Domain 7 - Role relationships /Domain 9 - Coping/stress tolerance}

Diagnoses: Risk for impaired parenting; Risk for caregiver role strain; Interrupted family processes; Risk for impaired attachment; Parental role conflict; Ineffective role performance; Powerlessness; Fear.

Nursing prescriptions: include parent in caring for the newborn; Stimulate bonding, offering lap, kangaroo position, touch; Allow free entry to parents in the unit; Offer active listening; Refer parents to psychological care when needed.

\section{Domain 11 - Safety/protection}

Diagnoses: Risk for infection; Risk for aspiration; Risk for shock; Impaired skin integrity; Risk for bleeding; Risk for imbalanced body temperature.

Nursing prescriptions: perform permeabilization of venous accesses and dressing changes with aseptic technique; change gastric tube, extensors and taps every 72 hours; change diet equipment every 24 hours; protect the syringe with gauze during gavage; maintain proclivity at 30 degrees; Verify gastric tube placement before administering the diet; monitor vital signs, urinary volume, capillary refill time greater than 3 seconds and lethargy; maintain permeable venous access; perform dressing change of surgical incision, communicate the presence of phlogistic signs and suture dehiscence; avoid skin contact with damp surfaces; perform change of decubitus and rigorous rotation of the oximeter sensor; communicate hyperemia in bony 
prominences; perform diaper change whenever necessary; avoid friction and shear; report presence of nasal bleeding, orotracheal, hematuria, live blood in stool and bloody exudate in operative wound; maintain incubator heated and humidified; maintain fist-iris of the incubator; keep temperature sensor on the skin of the newborn; perform restricted and grouped handling; report hypothermia and hyperthermia.

\section{Domain 12 - Comfort}

\section{Diagnoses: Impaired comfort and Acute pain}

Nursing prescriptions: keep newborn properly positioned in the nest; perform a change of decubitus, avoid ventral positioning during the first 48 hours postoperative period; avoid brightness; keep the environment quiet; promote skin-to-skin contact when possible; perform pain scale (NIPS), communicate score equal to or greater than 3; promote non-pharmacological measures for pain relief during painful procedures such as restraint, binding, non-nutritive suction, oral glucose $25 \%$; minimize visual and auditory stimuli.

\section{Domain 13 - Growth/development}

Diagnosis: Risk for delayed development

Nursing prescriptions: perform anthropometric measurements, such as height, weight and cephalic, thoracic, and abdominal perimeters; report weight loss.

\section{DISCUSSION}

It is known that the appendix in newborns is still in the embryonic form, i.e. in a funnel widely open towards the cecum and less prone to obstruction as in the "finger" form seen in older children. In addition, there are other aspects that make NA a rare pathology, such as the liquid and mild diet offered to this age group, thereby preventing the formation of fecaloma; maintaining a reclining posture; and lymphatic hyperplasia due to viral infections, which is infrequent in the neonatal period ${ }^{(1)}$.

The risk factors that trigger this pathology are mostly ischemic, and the perinatal history is of great importance in the pathogenesis of the disease. The examples cited in the literature are neonatal hypoxia, preeclampsia, umbilical catheterization, prematurity, and a clinical picture compatible with NEC. Several forms of vascular insufficiency associated with cardiac abnormalities and states of low blood flow also predispose to $\mathrm{NA}^{(1)}$.

Some obstructive pathologies may cause increased pressure at the base of the appendix, progressing to perforation, such as congenital megacolon, cystic fibrosis, NEC, inguinal hernia, meconium plug syndrome and meconium ileus, chorioamnionitis, and sepsis due to Group A streptococcus. For this motive, an associated condition should always be suspected. When this is not present, NA is considered a form of NEC limited to the appendix ${ }^{(1,4,8)}$.

The clinical picture is characterized initially by enteral alimentary intolerance, such as bilious emesis (80\%) and abdominal distension $(60 \%)$, hyperthermia, dehydration and moderate respiratory discomfort, pain with generalized sensitivity, irritability/hypoactivity, and tachycardia. As local implications, there may be scrotal edema, palpable mass in the lower right quadrant, and edema/erythema in the abdominal wall, all of these skin signs resulting from intra-abdominal cellulitis secondary to the inflammation ${ }^{(4)}$.

Corroborating the findings presented here, the literature also refers to laboratory screening with leukocytosis, thrombocytopenia, arterial blood gas analysis with hydroelectrolytic disorders and elevated CRP(1). However, such changes at the onset of symptoms may be insufficient to raise the hypothesis of appendicitis, since they are non-specific data ${ }^{(4)}$.

Abdominal radiographs with hydro aerial levels in the right iliac fossa, absence of distal air, subdiaphragmatic free-air, and opaque images are abnormal findings. Scoliosis to the right, free peritoneal fluid, thin abdominal wall and fecalomas can also be visualized, as well as pneumoperitoneum ${ }^{(1)}$. If the first radiograph does not show any significant changes, a second radiological evaluation is recommended, since the clinical picture may evolve with pneumoperitoneum due to rupture of the viscera ${ }^{(4)}$.

Because of the rarity of this pathology in the neonatal period, the diagnosis is tardive and the condition progresses rapidly to perforation and peritonitis in $80 \%$ of cases. This high index is due to the following factors: the appendicular wall is very thin and has insufficient blood flow; the omentum is poorly developed in the abdominal cavity and insufficient to prevent infection and allowing a more rapid peritoneal contamination; low cecal elasticity; and low resistance to infections at this age ${ }^{(8)}$.

Although the mortality rate has reduced significantly from $78 \%$ to $28 \%$ since the previous decade, a timely diagnosis is an exception ${ }^{(5,9)}$, given that no case of NA described in the literature was diagnosed preoperatively ${ }^{(4)}$. Generally, the findings suggest acute abdomen and only in the intraoperative period it is confirmed to be appendicitis ${ }^{(5)}$.

The primary management is exclusively surgical. Timely intervention is the ideal pre-evolution treatment for peritonitis secondary to visceral perforation. The newborn is submitted to exploratory laparotomy, resection of the compromised appendix and revision of the abdominal cavity followed by rinsing with warm saline solution. During the postoperative period, he received intravenous antibiotic therapy and absolute fasting for ten days with total parenteral nutrition. Oral diet is resumed only when intestinal transit is restored $(8,10)$. These recommended interventions are similar to the present case and demonstrate the technical competence and commitment of the medical and nursing team that attended the newborn M.H.O.

Consequently, the prognosis depends on the rapidity between diagnosis and surgical intervention, since the incidence of perforation is high (over $80 \%)^{(10)}$ and mortality can reach a rate of up to $100 \%{ }^{(1)}$.

\section{Study limitations}

As a limitation, it is underscored we reported a single case in the institution. Therefore, further investigation is suggested into this and other rare pathologies so that the multi-professional performance is effective and timely.

\section{Contributions to Nursing, health or public policy}

The study contributed to the nursing team searching for theoretical-practical knowledge. The Systematization of Nursing Care 
was fundamental to provide the newborn with the best treatment and survival, as demonstrated in this case in which a death was avoided. It is also important to divulge this case to the scientific community, since it is a rare pathology in the neonatal scenario.

\section{CONCLUSION}

Clinical surveillance should be established when the newborn presents with peritoneal irritation. Precise follow-up of the evolution and worsening of symptoms by nurses, as part of the care team and partner to the medical team, enables early surgical intervention, besides avoiding complications such as septicemia and death.

The success of this therapeutic approach, besides preserving the life of a child and contributing to the happiness of a family; produces a state of satisfaction in the health team that strengthens motivation for continuous learning and contributes to human development.

\section{REFERENCES}

1. Reyes LAG, González FMV, Arenas MAC. Apendicitis neonatal: presentación de dos casos. Rev Mex Pediatr [Internet]. 2001 [cited 2015 May 10];68(6):248-51. Available from: http://www.medigraphic.com/pdfs/pediat/sp-2001/sp016g.pdf

2. Khan RA, Menon P, Rao KLN. Beware of neonatal appendicitis. J Indian Assoc Pediatr Surg [Internet]. 2010 [cited 2015 Jun 02];15(2):[67-9]. Available from: https://www.ncbi.nlm.nih.gov/pmc/articles/PMC2952781/

3. Khan YA, Zia K, Saddal NS. Perforated neonatal appendicitis with pneumoperitoneum. APSP J Case Rep [Internet]. 2013 [cited 2015 Apr 14];4(2). Available from: https://www.ncbi.nlm.nih.gov/pmc/articles/PMC3754406/

4. Barbosa ADM, Figueiredo Júnior I, Caetano RR, Lopes VGS, Santos AM, Franco ED. Apendicite em recém-nascido prematuro. J Pediatr [Internet]. 2000 [cited 2015 May 04];76(6):466-8. Available from: http://www.jped.com.br/conteudo/00-76-06-466/port. pdf

5. Saeki I, Yamanouchi T, Tanaka S, Kawanami T, Mori R, Zaizen Y. Neonatal appendicitis mimicking intestinal duplication: a case report. J Medical Case Reports [Internet]. 2012 [cited 2015 Jun 02];6(286):1-3. Available from: https://jmedicalcasereports. biomedcentral.com/articles/10.1186/1752-1947-6-286

6. Zanardo GM, Zanardo GM, Kaefer CT. Sistematização da Assistência de Enfermagem. Rev Contexto Saúde [Internet]. 2011 [cited 2017 Feb 1];10(20):1371-4. Available from: http://www.revistas.unijui.edu.br/index.php/contextoesaude/article/view/1811

7. NANDA International. Diagnósticos de Enfermagem da Nanda: Definições e Classificação 2012-2014.

8. Gupta V, Sharma SB. Neonatal appendicitis with perforation: a case report and review of literature. J Indian Assoc Pediatr Surg [Internet]. 2005 [cited 2015 Oct 17];10(3):179-80. Available from: http://medind.nic.in/jan/t05/i3/jant05i3p179g.pdf

9. Jahangiri M, Hosseinpour M, Jazayeri H, Mohammadzadeh M, Motaharizad D, Mirzadeh AS. Perforated acute appendicitis in a pre-term neonate. Iran Red Crescent Med J [Internet]. 2013 [cited 2015 May 01];15(6):497-9. Available from: https://www.ncbi. nlm.nih.gov/pmc/articles/PMC3840837/

10. López-Valdés JC, Escarcega-Servin R. Apendicitis neonatal (AN) en un paciente con enterocolitis necrosante (ECN) secundaria a sepsis in utero. Gac Med Mex [Internet]. 2016 [cited 2015 Apr 14];152:419-23. Available from: http://www.anmm.org.mx/ GMM/2016/n3/GMM_152_2016_3_419-423.pdf 